\title{
PREVALENCE OF "NON-ORAL” PATHOGENIC BACTERIA IN SUBGINGIVAL BIOFILM OF SUBJECTS WITH CHRONIC PERIODONTITIS
}

\author{
Renata Souto $^{1 *}$; Arnaldo Feitosa B. de Andrade² ${ }^{2}$ Milton Uzeda $^{1}$; Ana Paula Vieira Colombo ${ }^{1}$ \\ ${ }^{1}$ Instituto de Microbiologia, Universidade Federal do Rio de Janeiro, RJ, Brasil; ${ }^{2}$ Departamento de Microbiologia, Universidade \\ Estadual do Rio de Janeiro, Rio de Janeiro, RJ, Brasil
}

Submitted: January 03, 2005; Returned to authors for corrections: May 30, 2005; Approved: April 24, 2006

\begin{abstract}
The oral cavity may act as a reservoir for several pathogens related to systemic infections. Therefore, the purpose of this study was to determine the prevalence and levels of pathogenic bacteria in the subgingival biofilm of chronic periodontitis lesions and healthy periodontal sites using the checkerboard DNA-DNA hybridization technique. 200 samples of subgingival biofilm from sites with periodontitis (probing pocket depth $\geq 4 \mathrm{~mm}$ and /or clinical attachment level $\geq 4 \mathrm{~mm}$ ) and 200 samples from healthy sites of 14 patients with chronic periodontitis, as well as 200 samples from 3 periodontally healthy patients were obtained. The presence and levels of 11 pathogenic bacteria were determined using whole genomic DNA probes and the checkerboard method, computed for each site and then across sites within each subject group. Significance of differences in clinical and microbiological parameters among groups were examinated using the MannWhitney and Wilcoxon sign tests. The predominant species in all 600 samples included Corynebacterium diphtheriae, Enterococcus faecalis, Staphylococcus aureus, Acinetobacter baumannii and Escherichia coli. In general, most of the species were detected in greater prevalence and levels in sites with and without disease from patients with periodontitis in comparison to the periodontally healthy group. In particular, $C$. diphtheriae, E. coli, E. faecalis, Pseudomonas aeruginosa and S. aureus were significantly more prevalent and detected in higher counts in diseased sites of patients with periodontal disease compared to healthy subjects $(\mathrm{p}<0.05)$. Clinical signs of disease presented a positive correlation with the species A. baumannii, Streptococcus pyogenes, E. coli, S. aureus and P. aeruginosa. In conclusion, "non-oral" pathogenic bacteria are detected in high prevalence and levels in periodontal sites of chronic periodontitis patients.
\end{abstract}

Key words: "non-oral" bacteria, periodontal disease, checkerboard and DNA probes

\section{INTRODUCTION}

Epidemiological studies have suggested that oral infection, specially periodontitis, may be a risk factor for systemic diseases, including respiratory diseases, cardiovascular diseases, and stroke $(1,20,31,32)$. Periodontal diseases are bacterial infections associated with a complex microbiota of the dental biofilm, composed predominantly by strictly anaerobic Gram - negative species. These microorganisms induce a local and systemic inflammatory response that will lead to periodontal tissue destruction (25). The mechanisms by which periodontal diseases might increase the risk for systemic diseases is not totally understood. The teeth are the only non-shedding surface in the body, and bacterial levels can reach more than $10^{11}$ microorganisms per mg of dental biofilm, particularly in the presence of periodontitis. The anatomic closeness of this biofilm to the bloodstream can facilitate the systemic spread of bacteria and their products, as well as inflammatory mediators and immunocomplexes $(1,31)$. The high incidence of bacteremia following dental procedures has been well documented $(9,14,23,24)$. It has been reported that one minute after a dental procedure, organisms from the infected oral site may reach the

*Corresponding Author. Mailing address: R. Dr. Abelardo de Barros, Casa 4, Tijuca. 20521-030, Rio de Janeiro, RJ, Brasil. Telefax: (+5521) $2569-7517$. E-mail: renatasouto@aol.com 
heart, lungs, and the peripheral blood capillary system (19). Likewise, it is possible that the oral cavity acts as a reservoir for other pathogenic species to disseminate to distant body sites, specially in immunocompromised hosts. For instance, a higher prevalence of respiratory pathogens such as Pseudomonas aeruginosa colonizing the dental biofilm has been observed in hospitalized patients and elderly institutionalized individuals (31). In addition, Helycobacter pylori, a pathogen associated with the development of peptic ulcers and gastric cancer, has been frequently detected in the dental biofilm and saliva of subjects with periodontitis (21). One aspect that should be pointed out is that eradication of these pathogens from dental biofilm may be more difficult due to their greater resistance to antimicrobials, increasing the risk of treatment failure and reinfection in these individuals $(8,32)$. Therefore, the purpose of this study was to determine the prevalence and levels of 11 pathogenic bacteria associated with medically important systemic diseases in subgingival dental biofilms obtained from periodontal sites of subjects with chronic periodontitis and periodontal health using the checkerboard DNA-DNA hybridization technique.

\section{MATERIALS AND METHODS}

\section{Study population}

Subgingival biofilm samples were obtained from 14 patients with chronic periodontitis who sought dental treatment at the Periodontology Department of the Federal University of Rio de Janeiro and Estácio de Sá University, and 3 periodontally healthy volunteers, as previously described (5). All periodontitis subjects were $\geq 35$ years of age, had at least 20 teeth, and showed at least 7 sites with probing pocket depths (PPD) $\geq 4 \mathrm{~mm}$ and clinical attachment level (CAL) $\geq 3 \mathrm{~mm}$ at baseline. These patients reported no history of any kind of periodontal therapy. Periodontal healthy individuals had no sites with PPD or CAL $\geq$ $3 \mathrm{~mm}$ and were $\geq 30$ years of age. Exclusion criteria included pregnancy, systemic conditions that could affect the progression or treatment of periodontal diseases, and use of antibiotics 6 months prior to the entry into the study. All patients were informed about the nature of the study and a signed consent form was obtained from each individual. The study protocol was approved by the Review Committee for Human Subjects of the University Hospital Clementino Fraga Filho (UFRJ).

Periodontal clinical measurements were performed at 6 sites per tooth at all teeth excluding third molar, and included dichotomous measures of suppuration, bleeding on probing, and supragingival biofilm accumulation, as well as PPD and $\mathrm{CAL}(\mathrm{mm})$. Two calibrated examiners performed all measurements for each subject. After clinical measurements, subjects with evidence of destructive periodontal disease received full mouth scaling and root planing under local anesthetic and instructions in proper home care procedures (12).

\section{Specimen sampling}

200 samples of subgingival biofilm from sites with periodontitis (PPD $\geq 4 \mathrm{~mm}$ ) and 200 samples from healthy sites were obtained from 14 chronic periodontitis patients. In addition, 200 samples were collected from periodontal sites of 3 individuals with no evidence of any form of periodontal disease. After removal of supragingival biofilm with sterile gaze, each sample was taken using sterile Gracey curettes and placed in individual tubes for microbiological analysis.

\section{Microbiological Assessment}

As previously reported $(5,37)$ the subgingival samples were lysed, and denaturated DNA fixed in individuals lanes on a nylon membrane using the checkerboard slot blot device (Minislot 30, Immunetics, Cambridge, MA). Eleven digoxigeninlabeled whole genomic DNA probes (Table 1) were hybridized at $90^{\circ}$ to the lanes of the biofilm samples using the Miniblotter 45 device (Immunetics). Bound probes were detected using phosphatase-conjugated antibody to digoxigenin and chemiluminescence. Signs were evaluated visually by comparison with the standards at $10^{5} \mathrm{e} 10^{6}$ bacteria cells for the test species on the same membrane. They were recorded as : 0 $=$ not detected $;=<10^{5}$ cells; $2 \cong 10^{5} ; 3=10^{5-1} 10^{6}$ cells; $4 \cong 10^{6}$; $5=>10^{6}$ cells. The sensitivity of this assay was adjusted to permit detection of $10^{4}$ cells of a given species by adjusting the concentration of each DNA probe. This procedure was carried out in order to provide the same sensitivity of detection for each species. Failure to detected a signal was recorded as zero, although conceivably, counts in the 1 to 1,000 ranges could have been present. A total of 600 plaque samples was evaluated, providing a total of 25,800 counts.

Table 1. Bacterial species used for the construction of whole genomic DNA probes tested against subgingival biofilm samples.

\begin{tabular}{lc}
\hline \multicolumn{1}{c}{ Species } & Strains * \\
\hline Acinetobacter baumannii & 19606 \\
Bacillus cereus & 14579 \\
Bacteroides fragilis & 25285 \\
Corynebacterium diphtheriae & 13812 \\
Enterococcus faecalis & 29212 \\
Escherichia coli & 33780 \\
Haemophilus influenzae & 33533 \\
Klebsiella pneumoniae & 700603 \\
Pseudomonas aeruginosa & 27853 \\
Staphylococcus aureus & 3359 \\
Streptococcus pyogenes & 8668 \\
\hline
\end{tabular}

*ATCC (American Type Culture Collection, Rockville, MD). 


\section{Statistical Analysis}

The statistical program SPSS, Statistical Package for the Social Sciences, version 9.0 (Chicago, IL) was used for all the analyses. Clinical measurements were averaged for all sites in each subject and then across subjects within each group. Differences in mean clinical parameters among groups were determined using the Mann-Whitney and Wilcoxon sign tests. Subgingival samples were individually analyzed for their content of 11 subgingival species using the checkerboard DNA-DNA hybridization technique. Microbial data were expressed as mean $\%$ of colonized sites (prevalence) and mean counts X $10^{5}$ (level) for each species. In the analysis of prevalence, it was considered the absence or presence of the microorganism. The levels of different species were determined by transforming the scores 0 to 5 obtained from de controls $10^{5}$ and $10^{6}$ in bacterial counts. The mean frequency and levels of each bacteria was computed for each subject and averaged across subjects within the groups. Significance of differences in prevalence and levels among groups was determined using the Mann Whitney test, whereas differences between healthy and diseased sites within the chronic periodontitis group were examined by the Wilcoxon sign test. Relationships between periodontal clinical parameters and microbial data were examined by bivariate correlation analysis. Differences of $p<0.05$ were considered statistically significant.

\section{RESULTS AND DISCUSSION}

Studies have suggested that periodontal infections and oral bacteria may be risk factors for a number of prevalent systemic diseases (20,31). Likewise, pathogens that cause these medically important diseases may harbor the oral cavity. The present investigation examined a large number of subgingival biofilm samples from periodontal sites of patients with chronic periodontitis and periodontal health for the presence and levels of 11 non-oral pathogenic bacteria using the checkerboard DNA-DNA hybridization technique.

\section{Clinical features}

Table 2 presents the clinical parameters evaluated in the 3 groups. As expected, periodontitis sites showed significantly more signs of disease, including higher mean PPD $(\mathrm{p}<0.001)$, mean CAL $(\mathrm{p}<0.001), \%$ of sites with supragingival biofilm accumulation $(\mathrm{p}<$ $0.001)$ and bleeding on probing ( $\mathrm{p}<0.001)$, as compared to periodontally healthy sites from patients with periodontitis (Wilcoxon test) and periodontal health (Mann-Whitney test). Interestingly, healthy sites from patients with health. periodontitis showed significantly more signs of disease compared to healthy sites from patients with no disease ( $\mathrm{p}<$ 0.05 , Mann-Whitney). This observation may indicate that individuals with periodontitis are somehow more susceptible to disease, either due to genetic, immunological or local factors such as a more intense inflammatory response or deficiency in plaque control (11).

\section{Microbiological findings}

The microbiological data demonstrated that the 11 pathogenic bacterial species examined in this study were detected quite commonly in the subgingival biofilms (Figs. 1 and 2). The species detected in higher prevalence (Fig. 1) and levels (Fig. 2) in the total 600 subgingival biofilm samples were: Corynebacterium diphtheriae, Enterococcus faecalis, Staphylococcus aureus, Acinetobacter baumannii and Escherichia coli. In general, the majority of the species was more predominant in sites with periodontitis. A significant higher prevalence of C. diphtheriae, E. coli, E. faecalis, Klebsiella pneumoniae, Pseudomonas aeruginosa and S. aureus was observed in diseased sites of periodontitis patients compared to periodontally healthy subjects $(\mathrm{p}<0.05$; Mann-Whitney test, Fig. 1). Acinetobacter baumannii was significantly more frequent in diseased sites than healthy sites within the periodontitis group ( $\mathrm{p}=0.03$; Wilcoxon sign test, Fig. 1). Conversely, K. pneumoniae and Bacillus cereus were observed in higher frequency in healthy sites than in sites with periodontitis in this group (Fig. 1). When comparing healthy sites in the two subject groups, E. coli, E. faecalis and $K$. Pneumoniae were significantly more prevalent in healthy sites of periodontitis patients than the sites from subjects with

Table 2. Mean $( \pm$ SEM) of periodontal clinical parameters from periodontitis and periodontally healthy sites of subjects with chronic periodontitis and periodontal

\begin{tabular}{lccc}
\hline \multirow{4}{*}{ Clinical Parameters } & \multicolumn{2}{c}{$\begin{array}{c}\text { Periodontitis } \\
\text { subjects }(\mathrm{N}=14)\end{array}$} & $\begin{array}{c}\text { Healthy } \\
\text { subjects }(\mathrm{N}=3)\end{array}$ \\
\cline { 2 - 4 } & $\begin{array}{c}\text { Diseased sites } \\
(\mathrm{N}=200)\end{array}$ & $\begin{array}{c}\text { Healthy sites } \\
(\mathrm{N}=200)\end{array}$ & $\begin{array}{c}\text { Healthy sites } \\
(\mathrm{N}=200)\end{array}$ \\
\hline Probing pocket depth $(\mathrm{mm})$ & $4.6 \pm 0.1^{*}$ & $2.4 \pm 0.07^{\#}$ & $1.8 \pm 0.04^{\dagger}$ \\
Clinical attachment level $(\mathrm{mm})$ & $4.5 \pm 0.1^{*}$ & $2.3 \pm 0.07^{\#}$ & $1.8 \pm 0.04^{\dagger}$ \\
\% of sites with: & & & \\
Supragingival biofilm & $82 \pm 3^{*}$ & $45 \pm 2^{\#}$ & $27 \pm 4^{\dagger}$ \\
Bleeding on probing & $56 \pm 7^{*}$ & $27 \pm 5^{\#}$ & $8 \pm 1^{\dagger}$ \\
\hline
\end{tabular}

* Refers to Mann-Whitney test for the diseased sites from periodontitis and healthy sites from healthy patients ( $\mathrm{p}<0.001)$; ${ }^{\dagger}$ Refers to Mann-Whitney test for the healthy sites of periodontitis and healthy subjects $(\mathrm{p}<0.05)$; ${ }^{\#}$ Refers to the Wilcoxon test for the diseased and healthy sites within the periodontitis group $(\mathrm{p}<0.001)$. 
periodontal health $(\mathrm{p}<0.01$, Mann-Whitney test, Fig. 1). Regarding the levels of the species evaluated, $C$. diphtheriae,

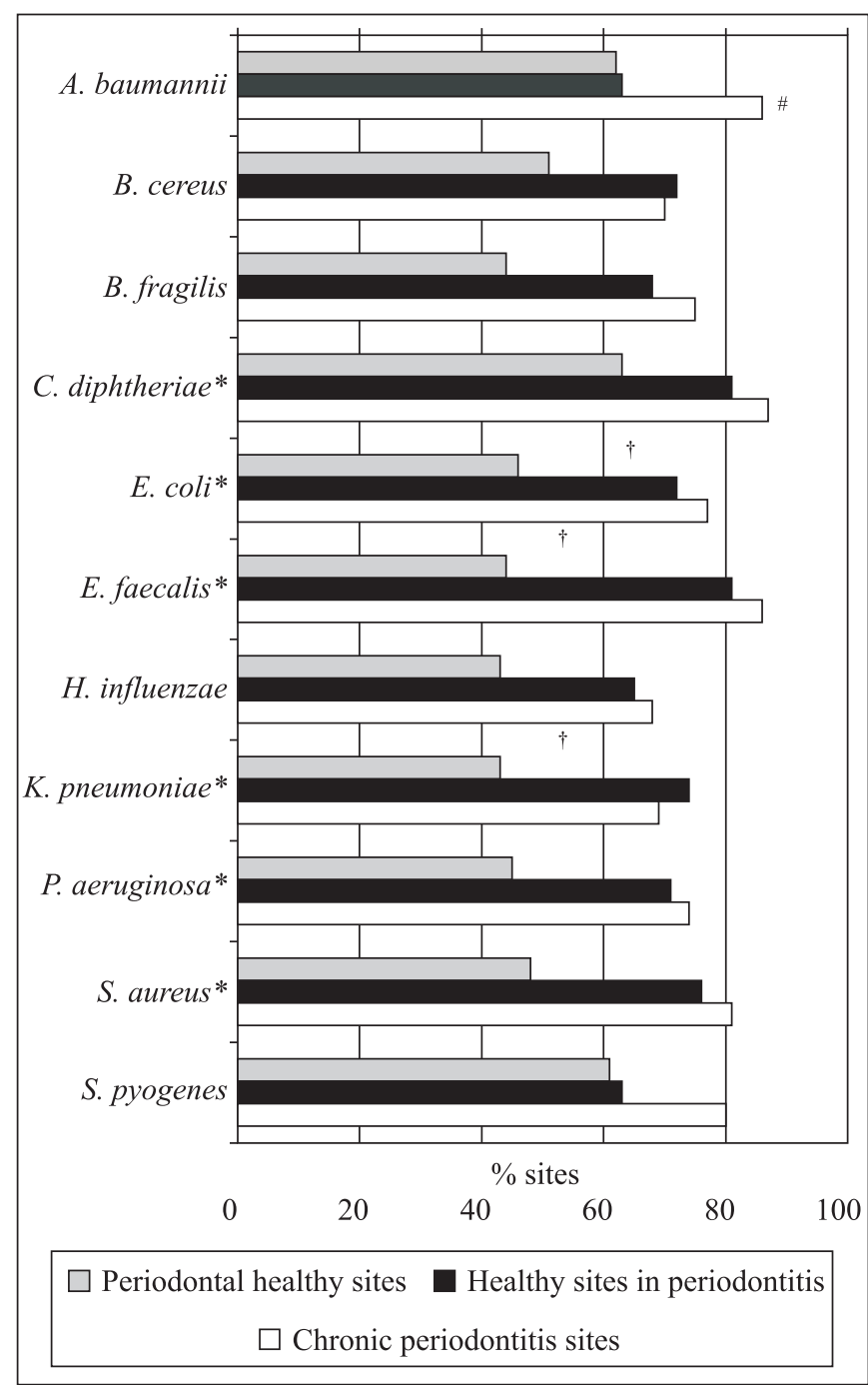

Figure 1. Stacked bar chart of frequency of detection of pathogenic species in subgingival biofilms from periodontitis and healthy sites of 14 subjects with chronic periodontitis and 3 subjects with periodontal health. The significance of differences in prevalence of bacterial species among the groups was determined by the Mann-Whitney test. The Wilcoxon test was used for seek significant differences between diseased and healthy sites from subjects with periodontitis. ${ }^{*} p<0.05$ refers to the Mann-Whitney test between sites with periodontitis and healthy sites from subjects with periodontal health; ${ }^{\dagger} \mathrm{p}<0.05$ refers to the Mann-Whitney test between healthy sites from periodontitis and periodontally healthy subjects; \# Refers to the Wilcoxon test for the diseased and healthy sites within the periodontitis group $(\mathrm{p}=0.029)$.
E. coli, E. faecalis, P. aeruginosa and S. aureus were detected in significantly higher mean counts in diseased sites from

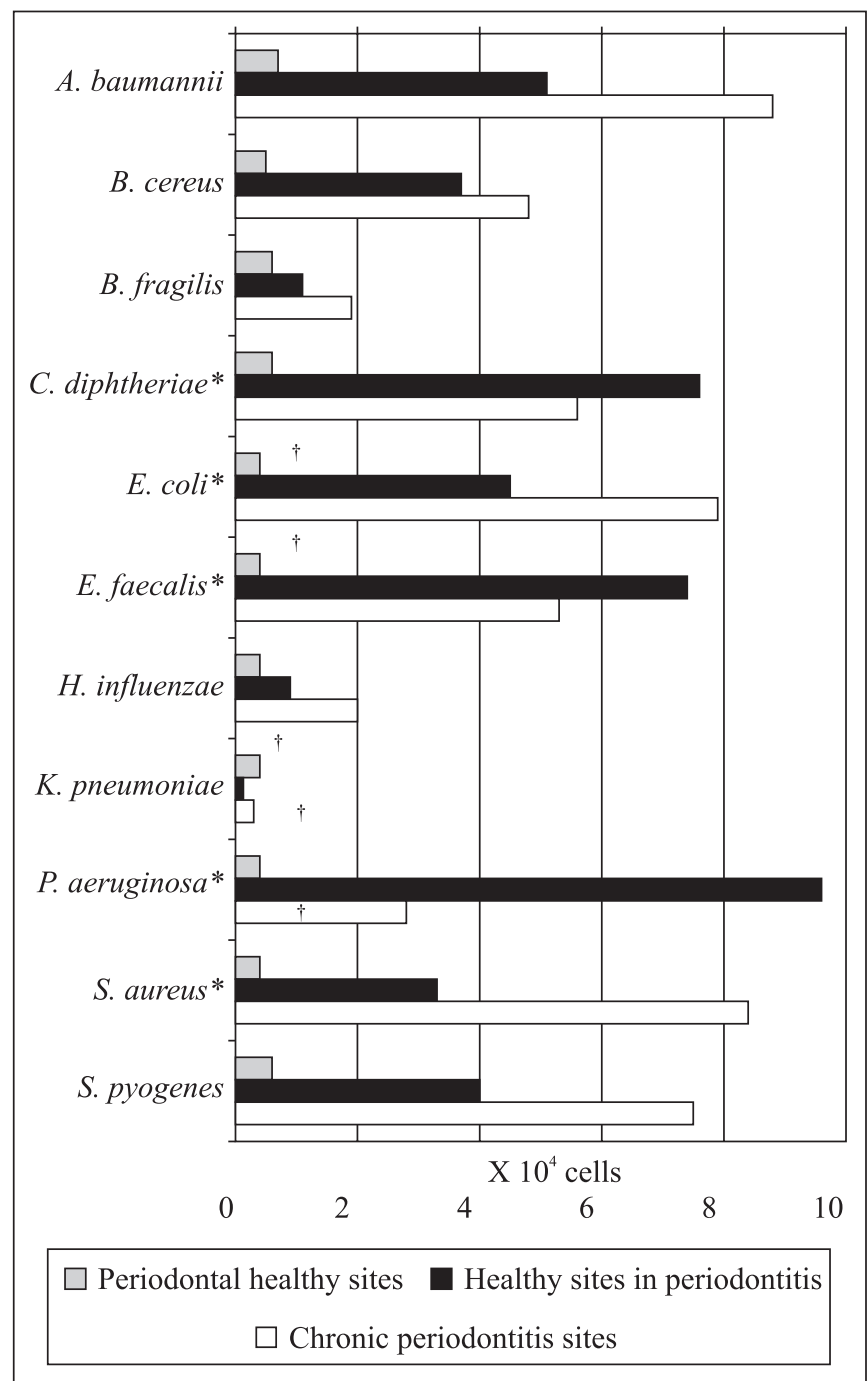

Figure 2. Stacked bar chart of mean counts (X 104 cells) of pathogenic species in subgingival biofilms from periodontitis and healthy sites of 14 subjects with chronic periodontitis and 3 periodontally healthy individuals. The significance of differences in levels of bacterial species among groups was determined by the Mann-Whitney test. The Wilcoxon test was used for seek significant differences between diseased and healthy sites from subjects with periodontitis. ${ }^{*} \mathrm{p}<0.05$ refers to the Mann-Whitney test between sites with periodontitis and healthy sites from subjects with periodontal health; ${ }^{\dagger} \mathrm{p}<0.05$ refers to the MannWhitney test between healthy sites from periodontitis and periodontally healthy subjects. No statistically significant differences in levels of bacteria were observed between diseased and healthy sites within the periodontitis group. 
periodontitis compared to periodontally healthy subjects ( $\mathrm{p}<$ 0.05; Mann-Whitney test, Fig. 2). In addition, significant higher levels of E. coli, E. faecalis, K. Pneumoniae, P. aeruginosa and $S$. aureus were found in healthy sites from patients with periodontitis than in sites from subjects with periodontal health ( $<$ < 0.05; Mann-Whitney test, Fig. 2). P. aeruginosa, E. faecalis and $C$. diphteriae presented greater mean counts in healthy sites from periodontitis patients, whereas $K$. pneumoniae was elevated in sites of subjects with periodontal health. No significant differences were observed in the levels of these species between diseased and healthy sites within the periodontitis group (Wilcoxon test; $p>0.05$; Fig. 2).

Accordingly to these results, several important pathogenic microorganisms have been identified in the oral cavity, such as H. pylori (21), B. cereus (15), viruses (7), S. aureus $(16,18,27,28)$, respiratory pathogens and enteric bacilli (32). These observations support the idea that the oral cavity may act as a reservoir and a source of these microorganisms to other area of the body. Moreover, established pathogens in the dental biofilm may be more difficult to eradicate due to their higher resistance to antimicrobials and the immunological defense mechanisms, increasing the probability of re-infection and treatment failure (36). For instance, Umeda et al. (40) have reported that a patient with periodontal pockets retained $\mathrm{H}$. pylori in the oral cavity even after eradication of the bacterium from the stomach. Other authors have described the oral carriage of meticillin-resistant S. aureus (MRSA) (30,39). In addition, Miyake et al. (22) found that $19 \%$ of the S.aureus isolates from oral samples produced exfoliative toxin and $40 \%$ of them enterotoxins.

The prevalence of these species in the oral cavity seems to get greater proportions in the presence of periodontal infection. The microbiological findings revealed that periodontitis patients presented a quite higher prevalence and mean numbers of bacterial pathogens than healthy subjects, suggesting that the establishment of these microorganisms seems to be supported by the presence of a complex subgingival microbiota associated with periodontal disease. Considerable published data agree with these results; however, variations in the frequency of these microorganisms in dental biofilm are observed in those studies $(3,5,35,36)$. Recently, Colombo and co-workers (5) examined a large number of subgingival biofilm samples from periodontitis patients in a Brazilian population and reported the presence of species not frequently found in the subgingival microbiota, such as A. baumannii, Bartonella spp., E.coli, and E. faecalis. In addition, these species were more prevalent in sites with disease as compared to periodontally healthy sites. Likewise, Slots et al. (35) observed a prevalence of $23 \%$ of enteric rods and Acinetobacter spp. in the subgingival microbiota of periodontitis patients in the Dominican Republic, whereas Ali and co-workers (2) observed a frequency of $61.1 \%$ of enterics in the subgingival microbiota of periodontitis subjects from Romania. The species P. aeruginosa and A. baumannii, important etiologic agents of nosocomial infections, have been associated with refractory periodontitis, probably due to their elevated resistance to mechanical and antimicrobial therapies $(4,29,34)$. Another pathogen related to antimicrobial resistance is $E$. faecalis. This species has been isolated from periodontitis lesions (29). Furthermore, it is the major species associated with treatment failure and recurrence of endodontic infections (33). Conceivably, the complexity of the subgingival microbiota of periodontitis may favor the colonization by these "non-oral species". Several studies have reported strong associations between certain pathogens and oral bacterial such as $H$. pylori and Tannerella forsythia (40), as well as co-infection of herpesviruses with $T$. forsythia and/or Porphyromonas gingivalis $(6,18)$ in sites with periodontitis. The etiologic role of these pathogenic species and their relationship with oral bacteria in periodontal infections is not fully understood; although these observations might suggest a possible contribution to the etiology of these diseases.

A quite interesting finding was the higher prevalence and levels of pathogenic bacteria in healthy sites from patients with periodontitis compared to healthy sites of subjects with periodontal health (Figs. 1 and 2). These differences were significant for E. coli, E. faecalis, P. aeruginosa, K. Pneumoniae and $S$. aureus ( $<<0.05$; Mann-Whitney test). These results suggest a possible transmission from sites with periodontitis to healthy ones in the same individual. In fact, the incidence of cross-infection with oral pathogens among periodontal sites is a common event and it has been well documented $(13,38,41)$. Moreover, in the present study, non-oral pathogens were also commonly observed in periodontally healthy sites. These findings were also reported by other authors $(3,5,36)$. It should be noted, though, that the majority of these pathogens were detected in lower frequency and numbers in these sites when compared to periodontitis lesions.

Relationships between clinical measurements and bacterial species were examined. Table 3 presents the mean prevalence and levels of the species that showed the strongest correlations with clinical parameters of disease. A. baumannii, Streptococcus pyogenes, E. coli, $S$. aureus and $P$. aeruginosa presented a significant positive correlation with mean PPD, CAL, BOP and supragingival biofilm accumulation $(\mathrm{p}<0.05$; bivariate correlation analysis). These data suggest that these species may play a role in the progression of periodontitis.

Major differences regarding the recovery rate of bacterial pathogens from the oral cavity reported in several studies may result from the utilization of distinct methods of detection and identification of microorganisms, as well as differences in clinical oral status and subject populations. Furthermore, much of the existing data in literature relate to mucosal swabs and salivary rinses with relatively little information on dental biofilm samples. In the present investigation, we employed whole genomic DNA probes and the checkerboard method (37). Our findings, as well 
Table 3. Relationship between clinical parameters of periodontitis, and the prevalence and levels of pathogenic bacterial species detected in subgingival biofilms.

\begin{tabular}{lcccc}
\hline Bacterial species & PPD & CAL & Bleeding on probing & Supragingival biofilm \\
\hline & & Prevalence \\
S. pyogenes & $0.400^{*}(\mathrm{p}=0.03)^{\dagger}$ & $0.345(\mathrm{p}=0.06)$ & $0.468(\mathrm{p}=0.01)$ & $0.336(\mathrm{p}=0.07)$ \\
A. baumannii & $0.444(\mathrm{p}=0.01)$ & $0.428(\mathrm{p}=0.02)$ & $0.416(\mathrm{p}=0.02)$ & $0.322(\mathrm{p}=0.09)$ \\
S. aureus & $0.318(\mathrm{p}=0.09)$ & $0.242(\mathrm{p}=0.20)$ & $0.476(\mathrm{p}=0.009)$ & $0.349(\mathrm{p}=0.06)$ \\
E. coli & $0.307(\mathrm{p}=0.10)$ & $0.259(\mathrm{p}=0.17)$ & $0.395(\mathrm{p}=0.03)$ & $0.329(\mathrm{p}=0.08)$ \\
P. aeruginosa & $0.225(\mathrm{p}=0.24)$ & $0.157(\mathrm{p}=0.41)$ & $0.396(\mathrm{p}=0.03)$ & $0.267(\mathrm{p}=0.16)$ \\
\hline & & Levels & \\
S. pyogenes & $0.447(\mathrm{p}=0.01)$ & $0.403(\mathrm{p}=0.03)$ & $0.552(\mathrm{p}=0.002)$ & $0.380(\mathrm{p}=0.04)$ \\
A. baumannii & $0.417(\mathrm{p}=0.02)$ & $0.388(\mathrm{p}=0.04)$ & $0.431(\mathrm{p}=0.02)$ & $0.393(\mathrm{p}=0.03)$ \\
S. aureus & $0.391(\mathrm{p}=0.03)$ & $0.331(\mathrm{p}=0.08)$ & $0.573(\mathrm{p}=0.001)$ & $0.410(\mathrm{p}=0.03)$ \\
E. coli & $0.452(\mathrm{p}=0.01)$ & $0.381(\mathrm{p}=0.04)$ & $0.370(\mathrm{p}=0.05)$ & $0.295(\mathrm{p}=0.12)$ \\
\hline
\end{tabular}

* Spearman rho coefficient (bivariate correlation test); ${ }^{\dagger}$ level of significance; PPD: probing pocket depth; CAL: clinical attachment level.

as data from other studies $(3,5,38)$ demonstrated the usefulness of the checkerboard method in screening large numbers of samples for the presence of several microorganisms simultaneously, providing a large view of the microbiological profile of a determined population. Nevertheless, one concern in interpreting the present data would be the sensitivity and especificity of the DNA probes employed. The sensitivity of the probes used in this study was adjusted to permit detection of $10^{4}$ cells. All the DNA probes were tested against a battery of oral and non-oral species in different levels. Probes to A. baumannii, B. cereus, Bacteroides fragilis, C. diphtheriae, Haemophilus influenzae, $P$. aeruginosa and $S$. aureus did not exhibit crossreactions with any heterologous species tested under the conditions of the assay. When cross-reactions were observed, such as for the species E. faecalis, $S$. pyogenes, E. coli and $K$. pneumoniae, they were always within genera and quite limited, exceeding a ratio of 100:1 for homologous:heterologous species. In other words, a DNA probe should require > 100 times as many cells of a heterologous species to be present to provide the same signal as a given number of the homologous species $(10,38)$. Despite that, cross-reactions between closely related species or non-specific binding to unrelated and even unknown species target DNA in dental biofilm samples may have occurred, requiring that these results be interpreted with caution. This fact could also explain the higher prevalence of pathogenic species reported in the present study. For instance, Papapanou et al. (26) demonstrated a reasonable degree of agreement between the checkerboard method and culture procedures for the identification of selected bacterial species in subgingival biofilm sample; however, they observed a higher prevalence of the species tested when the checkerboard technique was used in comparison to the cultivation.
Finally, the present study clearly demonstrate that pathogenic bacterial species can be frequently isolated from the subgingival microbiota of periodontally healthy sites, and particularly in sites with chronic periodontitis. Further longitudinal studies are required to establish whether this is a transient presence. In addition, the role of these species in periodontal diseases should be investigated. Conceivably, the oral cavity may be considered a potential source of pathogenic species to cause infection in distant body sites when other more obvious foci have been eliminated. This is of major concern in immunocompromised subjects. Moreover, eradication of these species within a complex dental biofilm may be limited and result in treatment failure. Therefore, close attention should be given to periodontitis patients who may harbor pathogenic bacteria in the oral cavity in order to reduce the risk for development of systemic infections.

\section{ACKNOWLEDGMENTS}

This work was supported in part by Conselho Nacional de Desenvolvimento Científico e Tecnológico - CNPq, Fundação de Amparo à Pesquisa - FAPERJ and Coordenação de Aperfeiçoamento do Pessoal do Ensino Superior-CAPES, Brazil.

\section{RESUMO}

\section{Prevalência de bactérias patogênicas "não-orais" no biofilme dental subgengival de pacientes com periodontite crônica}

Apesar da extensa literatura sobre a associação de bactérias orais e doenças sistêmicas, tem se dado pouca atenção à cavidade oral como um reservatório de bactérias patogênicas "não-orais". 
A microbiota oral é constituída de mais de 300 espécies bacterianas já caracterizadas, além de organismos não cultiváveis que vêm sendo descobertos através de técnicas moleculares. O objetivo do presente estudo foi determinar a prevalência e os níveis de 11 bactérias patogênicas "não-orais" em sítios periodontais de pacientes com periodontite e de pacientes saudáveis, utilizando a técnica do "Checkerboard DNA-DNA hybridization". 200 amostras de biofilme subgengival de sítios doentes (PBS $\geq 4 \mathrm{~mm}$ e/ou NCI $\geq 4 \mathrm{~mm}$ ), 200 amostras de sítios saudáveis de 14 pacientes com periodontite e 200 amostras de sítios de 3 pacientes saudáveis foram selecionadas. A prevalência (\% de sítios colonizados) e os níveis de cada espécie bacteriana foram computados para cada sítio e dentro de cada grupo. Diferenças clínicas e microbiológicas entre os grupos foram avaliadas através dos testes de Mann-Whitney e Wilcoxon. As espécies que predominaram nas 600 amostras analisadas incluíram Corynebacterium diphtheriae, Enterococcus faecalis, Staphylococcus aureus, Acinetobacter baumannii e Escherichia coli. Em geral, a maioria das espécies estudadas foi detectada com maior freqüência e em níveis elevados nos sítios com e sem doença nos pacientes com periodontite em relação ao grupo com saúde periodontal. Em particular, $C$. diphtheriae, E. coli, E. faecalis, P. aeruginosa e S. aureus foram significantemente mais prevalentes e detectadas em maior número nos sítios doentes de pacientes com periodontite em relação aos sítios de indivíduos com saúde periodontal ( $\mathrm{p}<$ 0,05 ). Sinais clínicos de doença periodontal apresentaram uma correlação positiva com as espécies A. baumannii, Streptococcus pyogenes, E. coli, S. aureus e P. aeruginosa. Além disso, as espécies $S$. pyogenes e A. baumannii, $C$. diphteriae e E. faecalis, $C$. diphteriae e $S$. pyogenes, $S$. aureus e $P$. aeruginosa também demonstraram uma forte correlação positiva entre si. Bactérias patogênicas "não-orais" são detectadas em grande prevalência e altos níveis em sítios de pacientes com periodontite crônica.

Palavras-chave: bactérias "não-orais", doença periodontal, checkerboard e sondas de DNA

\section{REFERENCES}

1. The American Academy of Periodontology. Periodontal disease as a potential risk factor for systemic diseases (position paper). $J$. Periodontol., 69, 841-850, 1998

2. Ali, R.W.C.; Velcescu, M.C.; Jivanescu, B.; Skaug, N. Prevalence of 6 putative periodontal pathogens in subgingival plaque samples from Romanian adult periodontitis patients. J. Clin. Periodontol., 23, 133-139, 1996

3. Ali, R.W.C.; Martin, L.; Haffajee, A.D.; Socransky, S.S. Detection of identical ribotypes of Porphyromonas gingivalis in patients residing in the United States, Sudan, Romania and Norway. Oral. Microbiol. Immunol., 12, 106-111, 1997.

4. Colombo, A.P.; Haffajee, A.D.; Dewhirst, F.E. Clinical and microbiological features of refractory periodontitis subjects. J. Clin. Periodontol., 25, 169-180, 1998.
5. Colombo, A.P.; Teles, R.P.; Torres, M.C.; Souto, R.; Rosalém, W.; Mendes, M.C.S.; Uzeda, M. Subgingival microbiota of brazilian subjects with untreated chronic periodontitis. J. Periodontol., 73, 360-369, 2002.

6. Contreras, A.; Nowzari, H.; Slots, J. Herpesviruses in periodontal pocket and gingival tissue specimens. Oral Microbiol. Immunol., $15,15-20,2000$.

7. Contreras, A.; Slots, J. Typing of herpes simplex vírus from human periodontium. Oral Microbiol. Immunol., 16, 63-68, 2001.

8. Costerton, J.W.; Lewandowsk, I.Z.; Caldwell, D.E.; Korber, D.R.; Lappin-Scott, H.M. Microbial biofilms. Аnnu. Rev. Microbiol., 49, 711-716, 1995.

9. Drinnan, A.J.; Gogan, C. Bacteremia and dental treatment. J. Am. Dent. Assoc., 120, 378-382, 1990.

10. Gunarathan, M.; Smith, G.L.; Socransky, S.S.; Smith, C.M.; Haffajee, A.D. Enumeration of subgingival species on primary isolation plates using colony lifts. Oral Microbiol. Immunol., 7, 14-18, 1992.

11. Haffajee, A.D.; Socransky, S.S.; Lindhe, J.; Kent, R.L.; Okamoto, H.; Yoneyama, T. Clinical risk indicators for periodontal attachment loss. J. Clin. Periodontol., 18, 117-125, 1991.

12. Haffajee, A.D.; Cugini, M.A.; Dibart, S.; Smith, C.; Kent, R.L.; Socransky, S.S. The effect of SRP on the clinical and microbiological parameters of periodontal diseases. J. Clin. Periodontol., 24, 324334, 1997.

13. Haffajee, A.D.; Cugini, M.A.; Tanner, A. Subgingival microbiota in healthy, well-maintained elder and periodontitis subjects. J. Clin. Periodontol., 25, 346-353, 1998.

14. Heimdahl, A.G.; Hall, M.; Hedberg, H.; Sandberg, P.; Soder, O.; Nord, C.E. Detection and quantification by lisis-filtration of bacteremia after different oral surgical procedures. J. Clin. Microbiol., 28, 22052209,1990

15. Helgason, E.; Caugant, A.; Olsen, I.; Kolst A. Genetic Structure of population of Bacillus cereus and thuringiensis isolates and other human infections. J. Clin. Microbiol., 38, 1615-1622, 2000.

16. Jackson, M.S.; Bagg, J.; Gupta, N.M.; Sturrock, R.D. Oral carriage of staphylococci in patients with rheumatoid arthritis. J. Rheumatol., 38, 572-575, 1999.

17. Kamma, J.J.; Nakou, M.; Baehni, P.C. Clinical and microbiological characteristics of smokers with early onset periodontitis. $J$. Periodont., 34, 25-30, 1999.

18. Kamma, J.J.; Contreras, A.; Slots, J. Herpes viruses and periodontopathic bacteria in early-onset periodontitis. J. Clin. Periodontol., 28, 879-884, 2001.

19. Kilian, M. Systemic disease: manifestations of oral bacteria. In: McGhee, J.R.; Michalek S.M.; Cassel G.H. (eds), Dental microbiology, Harpers \& Row, Philadelphia, 1995, p.832-838.

20. Li, X.; Kolltveit K.M.; Tronstad, L.; Olden, I. Systemic diseases caused by oral infection. Clin. Microbiol. Rev., 13, 547-551, 2000.

21. Madinier, I.M.; Fosse, T.M.; Monteil R.A. Oral carriage of Helicobacter pylori: a review. J. Periodontol., 68, 2-6, 1996.

22. Miyake, Y.; Iwai, M.; Sugai, M.K.; Miura, K.; Suginaka, K.; Nagasaka, M. Incidence and characterization of Staphylococcus aureus from the tongues of children. J. Dent. Res., 70, 1045-1050, 1991.

23. Navazesh, M.; Mulligan R. Systemic dissemination as a result of oral infection in individuals 50 years of age and older. Spec. Care Dentist., 15, 11-19, 1995.

24. Okabe, K.; Nakagawa, K.; Yamamoto, E. Factors affecting the ocurrence of bacteremia associated with tooth extraction. Int. J. Oral Maxillofac. Surg., 24, 239-242, 1995.

25. Page, R.C.; Kornman, K.S. The pathogenesis of periodontitis. Periodontol. 2000, 14, 9-11, 1997.

26. Papapanou, P.N.; Madianos, P.N.; Dahlén, G.; Sandros, J. "Checkerboard" versus culture: a comparison between two methods for identification of subgingival microbiota. Eur. J. Oral Sci., 105, 389-396, 1997 
27. Piochi, B.J.A.; Zelante, F. Contribution on the study of staphylococcus isolated from the mouth. III Staphylococcus isolated from dental plaque. Rev. Fac. Odont. São Paulo, 5, 91-95, 1995.

28. Rams, T.E.; Feik, D.; Slots, J. Staphylococci in human periodontal diseases. Oral Microbiol. Immunol., 5, 29-34, 1990.

29. Rams, T.E.; Feik, D.; Young, V.; Hammond, B.F.; Slots J. Enterococci in human periodontitis. Oral Microbiol. Immunol., 7, 249-254, 1992.

30. Rossi, T.; Peltonen, R.; Laine, J.; Eerola, E.; Vuopio-Varkila, J.; Kotilainen, P. Erradication of the long-term carriage of methicilliresistant Staphylococcus aureus in patients wearing dentures: a follow-up of 10 patients. J. Hosp. Infect., 34, 311-318, 1997.

31. Scannapieco, F.A. Position paper: periodontal disease as a potencial risk factor for systemic diseases. J. Periodontol., 69, 841-850, 1998.

32. Scannapieco, F.A. Role of oral bacteria in respiratory infection. $J$. Periodontol., 70, 793-802, 1990.

33. Siqueira, J.F.; Roças, I.N.; Souto, R.; Uzeda, M.; Colombo, A.P. Actinomyces species, streptococci, and Enterococcus faecelis in primary root canal infections. J. Endod., 28, 168-172, 2002.

34. Slots, J.; Feik, D.; Rams, T.E. Prevalence and antimicrobial susceptibility of Enterobacteriacea, Psedomonadaceaea and Acinetobacter in human periodontitis. Oral Microbiol. Immunol., 5, 149-154, 1990.
35. Slots, J.; Rams, T.E.; Feik, D.; Taveras, H.D.; Gillespie, G.M. Subgingival microflora of advanced periodontitis in the Dominican Republic. J. Periodontol., 62, 543-549, 1991.

36. Smith, A.J.; Jackson, M.S.; Bagg, J. The ecology of Staphylococcus species in the oral cavity. J. Med. Microbiol., 50, 940-946, 2001.

37. Socransky, S.S.; Smith, C.; Martin, L.; Paster, B.J.; Dewhirst, F.E.; Levin, T.E. "Checkerboard" DNA-DNA hybridization. Biotechniques, 17, 788-792, 1994.

38. Socransky, S.S.; Haffajee, A.D.; Cugini, M.A.; Smith, C.; Kent, Jr. R.L. Microbial complexes in subgingival plaque. J. Clin. Periodontol., 25, 134-144, 1998.

39. Tawara, Y.; Honma, K.; Naito, Y. Methicillin-resistance Staphylococcus aureus and Candida albicans on denture surfaces. Bull. Tokyo Dent. Coll., 37, 119-123, 1996.

40. Umeda, M.; Komatsubara, H.; Minamikawa, T.; Furudoi, S.; Shibuya, Y.; Yokoos, S. A questionnaire on requests for dislosure of diagnosis, self choice of treatment, and second opinion of patients with oral cancer in Japan. J. Palliat. Car., 19, 206-208, 2003.

41. Ximenez-Fyvie, L.A.; Haffajee, A.D.; Socransky S.S. Comparison of the microbiota of supra- and subgingival plaque in health and periodontitis. J. Clin. Periodontol., 27, 637-647, 2000. 